\title{
JUDGE AS A PUBLIC SERVANT
}

\author{
Yevheniia Zherobkina $^{1}$ \\ Dmytro Maletov ${ }^{2}$ \\ Volodymyr Sevruk ${ }^{3}$ \\ Serhii Pavlenko ${ }^{4}$ \\ Nataliia Serbyn ${ }^{5}$
}

Abstract: The topicality of this article is due to the intensification of the development and improvement of public administration in the world and the strengthening of the role of public service as a key characteristic of a democratic, rule of law state. The purpose of the article is to conduct a scientific study on the development of the model "judge-public servant" in Ukraine and the world. The leading research methods are general scientific and specific research methods, including methods of logic, analysis, comparison and more. The results of this study are the identification of the basic problems of functioning of the public service in Ukraine and the problems of determining the legal status of a judge as a public servant, as well as outlining the ways of overcoming problems. The significance of the results obtained is that the study may serve as a basis for outlining future changes to current legislation on the development of public service in Ukraine and the legal status of judges.

Keywords: public service, judge, judge of general jurisdiction, judiciary.

\section{Introduction}

The Constitution of Ukraine (1991) defines Ukraine as a rule of law in which a single state power is exercised on the principle of its division into branches of power: legislative, executive and judicial. An important factor that represents a single state power, regardless of its type, is the public

\footnotetext{
1 Sumy State University, Rimsky-Korsakov Street, 2, Sumy, 40007, Ukraine. E-mail: zherobkina18@tanu.pro

${ }^{2}$ Sumy State University, Rimsky-Korsakov Street, 2, Sumy, 40007, Ukraine

${ }^{3}$ National Academy of Internal Affairs, Solomjanska Square, 1, Kyiv, 03035, Ukraine

${ }^{4}$ National Academy of Internal Affairs, Solomjanska Square, 1, Kyiv, 03035, Ukraine

${ }^{5}$ National Prosecution Academy of Ukraine, Melnikov Street, 81-b, Kyiv, 04050, Ukraine
} 
service as a social and legal institution, designed to ensure, on the one hand, the practical implementation of the tasks of state and municipal authorities, and on the other - protection of the rights, freedoms and interests of individuals, rights and interests of legal entities in their relations with the state. The functioning of both the state and civil society depends on its professionalism and competence, authority and stability, provision and security (Tsurkan, 2010). The Constitution of Ukraine defined a system of governing the country through: state power and local selfgovernment bodies in Ukraine. Scientists call this system of government - public authority. In accordance with the basic law of our country in Ukraine a system of public authorities is created and operates, as a set of bodies of state power and local self-government established by the Constitution of Ukraine, which ensure the protection of the rights, freedoms and legitimate interests of citizens, the security of the state and society, solve issues of socio-economic and cultural construction. According to the provisions of the Constitution of Ukraine, this system is divided into the following links:
I. System of public authorities:

1. The Head of State is the President of Ukraine.

2. The only legislative body (Parliament) is the Verkhovna Rada of Ukraine.

3. The system of state bodies of executive power: The Cabinet of Ministers of Ukraine is the highest body in the system of state executive bodies; ministries, state committees, central bodies with special status - central bodies of executive power; local state administrations - local state executive bodies.

4. The system of state bodies of the judiciary.

II. System of authorities of the Autonomous Republic of Crimea:

1. The only representative body of autonomy is the Verkhovna Rada of the Autonomous Republic of Crimea.

2. System of executive bodies of autonomy: The Council of Ministers of the Autonomous Republic of Crimea is the highest executive body of autonomy; 
Ministries and Republican Committees are the central executive bodies of autonomy.

\section{System of local self-government:}

1. Representative bodies of local selfgovernment: village, settlement, city councils - bodies of local selfgovernment, representing the respective territorial communities and exercising on their behalf and in their interest the functions and powers of local selfgovernment; they are headed, respectively, by village, town and city mayors elected by the territorial communities; district and regional councils - bodies of local selfgovernment representing the common interests of territorial communities of villages, towns and cities; they are headed by the chairmen of these councils, who are elected by the councils themselves from among the deputies; regional in city councils - representative bodies of local self-government, which can be created by decision of the territorial community of the city or city council.

2. Executive bodies of local selfgovernment - executive committees, departments of rural, settlement, city, district and city councils and other executive bodies created by councils.

3. Bodies of self-organization of the population - house, street, quarter councils and committees, as well as councils of districts - can be created on the initiative of residents and with the permission of village, settlement, city councils (Yarmysh and Serohin, 2002).

O.S. Petrenko argues that in the first years of Ukraine's independence, scholars primarily defined the public service as a public service, that is, the professional activity of persons holding positions in state bodies and their apparatus aimed at practically fulfilling the tasks and functions of the state and receiving salaries at the expense of public funds. Recently, with the strengthening of the role of public administration, the search for meaningful filling of the term "public service" has become actual (Petrenko, 2008).

The Code of Administrative Procedure of Ukraine (2005) for the first time defined the concept of "public service", according to which public service is an activity in state political 
positions, in state collegial bodies, professional activity of judges, prosecutors, military service, alternative (non-military) service, other civil service, patronage service in state bodies, service in the authorities of the Autonomous Republic of Crimea, local self-government bodies. But this concept does not contain the essential characteristics and features of public activity, it provides only a list of activities that violate the rules of legal technology. Under these circumstances, the elucidation of the concept, nature, characteristics and types of public service and public servants is of particular importance.

In his scientific works of N.O. Runova (2012) noted that the above definition is not perfect, and therefore formulated an author's understanding of the concept: public service is the exercise of power by society (the people) through the professional activity of public servants. According to M.I. Tsurkan (2010), a concept contained in the CASU, cannot be considered as formulated in accordance with the rules of legal technology, since it includes only a list of types of public service, but does not express the essential characteristics of public administration.
Analyzing the concept of "public service". We consider it possible to distinguish the basic disadvantages: the existence of a list of types of service and employees does not make it possible to carry out the general characterization of the category, since new categories of persons are created in the system of government due to the constant development of public relations; the definition does not consolidate the basic features that could be attributed to public officials; the list contains incompatible types of employees, because politicians and civil servants, according to the theory of administrative law, belong to different classification groups depending on the content.

Ukraine's proclamation of a course on European integration and the need to meet the criteria and requirements for candidates for $\mathrm{EU}$ membership puts the task of creating a highly professional public service as a key element of an effective public administration system (Shatrava et al., 2019). L.L. Prokopenko emphasizes that this circumstance needs to take into account the experience of developed countries when justifying the parameters of the public service model in accordance with the requirements of the 
current stage of state formation (Prokopenko, 2009).

\section{Materials and Methods}

The following methods were used during the research: general theoretical (analysis, synthesis, concretization, generalization, analogy method, modeling); empirical methods (research of experience of functioning of public service and definition of legal status of judges through the prism of public service in Ukraine and the world, research of normative-legal and scientific-methodical literature on the subject, scientific researches and conclusions).

In order to comprehensively analyze the nature and place of public service in the system of national legislation, it becomes necessary to characterize it as a coherent management system through the determination of constituent elements. As noted above, the existing legislative definition of the term "public service", enshrined in the Code of Administrative Procedure of Ukraine, contains a non-exhaustive list of types of service to which the sphere of public administration applies. Therefore, in the context of our scientific research, it is advisable to consider and analyze the types of services that he has assigned to the public, such as:

\section{Political service.}

2. Public Service.

3. Military Service.

4. Alternative (non-military) service.

5. Local government service.

6. Judicial service.

Thus, one of the elements of public service is the service of the judiciary. Civil service in the judiciary is not limited to fulfilling the tasks and functions stipulated by the Law of Ukraine "On Judiciary and Status of Courts" (2016), which are related to the administration of justice. In order to ensure the functioning of the courts, to ensure the organization of their activity, the Law of Ukraine "On the Judiciary and Status of the Courts" (2016) provides for a number of services and government bodies that perform these tasks.

\section{R.Z. Holobutovskyi (2019)} emphasizes that given the general functions and tasks of the judiciary, the following types of public service can be identified: serving as a judge; service in the bodies providing the activities of courts and judges; service in government bodies and institutions of the justice 
system. When considering a judge as an element of the public service system, it is necessary to understand why he/she belongs to the category of public servants. First of all, this is due to the fact that:

a) although he/she holds a position in a public authority but does not refer to either state or political officials;

b) judges' decisions are made only in accordance with the Constitution of Ukraine, other laws and their own justice, not the interests of the state;

c) the justice exercised by the judge is intended to satisfy the interests of the public;

d) the judge is completely independent and resolves the issue of law (Paseniuk, 2009).

There is currently a problem with the legislative regulation of the professional service of judges as a separate type of public administration. Thus, as the Code of Administrative Judiciary of Ukraine (2005) attributes the activities of a judge to the public service, there is a need to consolidate their legal status in special legal acts, taking into account that they are public servants.
178

We believe that there is a serious gap in the legislation, namely the absence of the Law "On Civil Service" (2015), which would establish basic concepts, principles, tasks and provide for a specific system of public administration, is an unjustified inaction of the legislator. In order to create an effective system of public administration in Ukraine, it is not enough to consolidate one definition of a public service; it is necessary to define and consolidate the legal status of all persons holding public office. In our view, having a definition of a public service in national law is not a guarantee of its de facto existence. It is quite strange that the legal acts regulating the activity of certain types of public service, such as the Law of Ukraine "On Judiciary and Status of Judges" (2016), have been developed and adopted, but there is no basic legal act that would apply to all public servants. However, according to the regulations aimed at reforming the management and judicial system, the problem of securing the legal status of public officials, in particular judges, is one of the priorities today (Pchelina et al., 2019). Pursuant to paragraph 3 of the Sustainable Development Strategy "Ukraine 2020" No. 5/2015 dated 12 
January 2015, judicial reform is envisaged within the security vector, which is intended to ensure that the activities of professional judges are in line with the public vision of the judiciary and its independence. Improving the transparency and publicity of the judicial process has been key to reforming the judicial system in “Ukraine - 2020" (2015). In pursuance of the aforementioned regulatory act, the Strategy for the Reform of the Judiciary and Related Legal Institutions for 20152020 No № 276/2015 of 20.05.2015 was adopted. According to paragraph 3 of this Strategy, one of the main factors influencing the efficiency of the judicial system and justice is a high percentage of people's distrust of judges and a lack of publicity (Pchelina et al., 2019).

\section{Results and Discussion}

\section{Analysis of the Status of a Judge in the Legislative System of Ukraine}

It should be noted that the process of judicial reform and modernization in Ukraine has been going on for over 28 years and has not been completed yet. In addition, the analysis of the judicial practice shows that the sphere of organization of the judiciary in Ukraine has numerous shortcomings. The ineffectiveness and inefficiency of the judicial reform are also indicated by the results of the Razumkov Center for Sociological Studies among the citizens. In particular, the level of trust in the courts is one of the lowest in society. Thus, $77.7 \%$ of the respondents reported their lack of confidence in the judicial system as a whole. $69.7 \%$ of respondents, in turn, do not trust the courts of general jurisdiction (Assessment of the situation..., 2020).

Ukraine's becoming as a rule of law, a democratic state, for which the rights and freedoms of citizens is of the highest social value, is impossible without the creation of an independent, objective, honest and authoritative judiciary. The achievement of these goals is possible not only by improving the general principles of the organization of the judiciary in Ukraine, but also by carrying out a comprehensive reform of the public service (Shatrava et al., 2019). The most effective public service system that meets the national standards of developed European countries is one of the main conditions for the functioning of independent and highly respected judges of courts of general jurisdiction. 
Under public service in the judicial authorities of Ukraine, first of all, one should see the politically neutral, professional activity of a judge in courts, judicial administration bodies and other state bodies of the justice system and institutions for the organization and maintenance of the activity of courts and judges. This understanding is determined by the Bangalore Principles of Judicial Conduct approved by UNSCR 2006/23 (2006). The adjuration of a judge of a court of general jurisdiction shall be the commencement of his/her public service, which shall continue until such time as he/she will be removed from office by the body which elected or appointed him/her. In Art. 3 of the Law of Ukraine “On Civil Service” (2015) the legislator emphasizes that "... this law does not apply to judges...". Therefore, the law mentioned above does not actually refer to the posts of judges of the courts of general jurisdiction, neither political nor civil servants.

Instead, Art. 2 of the Law of Ukraine "On Judiciary and Status of Judges" (2016) stipulates that judges are officials of the judiciary. However, taking into account the nature of the changes that have taken place in the modern social, political and economic life of our country, taking into account the time of the adoption of the Law of Ukraine "On Judiciary and Status of Judges" (2016), we can state the urgent need to legislate the status of judges of courts of general jurisdiction as a fundamentally separate and distinct type of public service. The list of functions of judges of courts of general jurisdiction does not include any function of a political nature. Their primary responsibility is to resolve the issue of law through impartial and fair justice. Judges carry out their activity independently, while obeying only the requirements of the Constitution of Ukraine and being guided by the current legislative acts and personal justice. Although judges of courts of general jurisdiction hold public office, they do not and cannot have the status of civil servants.

The activities of civil servants by their legal definition presuppose the possibility of certain hierarchical relationships, accountability, dependency and control. The implementation of the functions of justice directly by the civil service would be contrary to the generally recognized constitutional principles of the organization of independent local 
judicial bodies of general jurisdiction. By its lexical meaning and interpretation of justice, it cannot be subordinated to something or someone, except for the task of protecting the legal rights, freedoms and interests of individuals and legal entities. However, judges of courts of general jurisdiction are part of the public service system of Ukraine and therefore are public servants. Strategic issues of increasing professionalism, efficiency of the activity of judges of courts of general jurisdiction and restoration of public confidence are defined by the Strategy of development of the judicial system in Ukraine for 2015-2020 (Syniavyna, 2014).

In the process of achieving the goals mentioned above, one should not forget the general specificity of the professional activity of public servants. Therefore, it is necessary to pay particular attention to the moral basis of judges of courts of general jurisdiction. One of the main regulators that determines the person's immediate actions and specific behavior is his or her individual moral orientation. It is this circumstance that determines the objective necessity of taking into consideration, along with the professionalism of a judge of a court of general jurisdiction, a moral factor. Honesty, principle, public service and other moral qualities are of major importance for judges of the courts of general jurisdiction in the exercise of their professional duties as public servants, since the activities of the judiciary should be maximally aimed at the implementation of the fundamental principles of the Constitution of Ukraine and other normative legal acts. The morality or immorality of actions of judges of courts of general jurisdiction must be judged not only by the final results of their activity, but also, in particular, by the level of their objective attitude to the assessment of the legality of certain actions during the process of preparing specific draft decisions in cases. Therefore, the personal requirements for judges of courts of general jurisdiction as public officials who play a particularly important role include: fairness, honesty, objectivity, impartiality, attentive attitude towards the fulfillment of one's professional duties, high level of demanding to others and to oneself personally, criticality, perseverance and patience in achieving the goal, etc.

The activity of judges of courts of general jurisdiction as public servants 
is characterized by the following features: judges of courts of general jurisdiction hold public office in the bodies of the state judiciary, and neither belong to the category of political or civil servants; special procedure for appointment and passing of judicial service; judges of courts of general jurisdiction are independent in their activity and subject only to the law; remuneration of judges of courts of general jurisdiction is paid from the state budget (Goncharuk, 2017). We believe that the mechanical transfer of international experience to the Ukrainian legal plane without taking into account the specifics of the legislation and legal culture of our country is unlikely to be able to achieve positive results. At the same time, a study of this kind will help to deliberately avoid possible problems and contradictions encountered by many foreign countries during the reform of public service.

\section{The Experience of Foreign Countries} in the Regulation of the Public Service System

Most countries in the world began their own path to modernization and radical change in public service in the late XX century, and as a result, today these processes have made it possible to significantly improve public sector performance. The Federal Republic of Germany is one of the first European countries to have a professional public service. According to the current "Federal Law on the Status of Officials", "public service" means the activities of employees whose main purpose is to fulfill national governmental tasks (Ahientaieva, 2012). Public servants, in particular, include: officials of the state apparatus, judges, prosecutors, teachers, teachers, doctors, railway workers, post offices, etc. It should be emphasized that in Germany the activity of judges of courts of general jurisdiction is carried out within the framework of the general public service and is not separated into a separate independent type of public service (Ahientaieva, 2012).

The Lithuanian Law on Public Service (1999) provides the following interpretation of the concept of public service, which should be considered: the totality of legal relations arising from the acquisition of the status of a public servant, the change or loss of this status, and also as a result of public administrative activity of a public servant in a state or municipal institution. 
The experience of France, according to which judges of courts of general jurisdiction are included in the system of public service of the state, but are not "servants" in the classical sense is significant. They serve neither political authority nor the state, the primary duty of the French judicial authorities is to serve the law only. Judges of courts of general jurisdiction, when resolving legal disputes of "the state against the person" or "the person against the state", take a position over the dispute and often make final decisions "against the state".

\section{Canada's Law “On Public}

Employment" provides for the separation of positions in public authorities into political, judicial and service sectors (Khorosheniuk, 2015). Despite the peculiarities of understanding the legal definition of public service in different foreign countries, it is worth noting that particular attention in modern legislation is devoted precisely to the regulation of the activities of public servants.

Most of the modern constitutions of foreign countries have in their content sections, basic provisions on the judiciary: "On the Judiciary" - the Constitution of France, Spain; "Justice"
- The Constitution of Germany; "Courts" - Portugal's Basic Law etc. Speaking about the legal regulation of the legal status of judges of courts of general jurisdiction in different countries of the world, in the vast majority of cases, it is implemented by enshrining the main provisions concerning judges as public servants in the general legal acts aimed at regulating the activities of the public service. The peculiarities of the activities of the judiciary are determined by other special laws. For example, the current Law "On Public Service" in Estonia (2002) states that this law applies to the Auditor General, the Chancellor of Justice, judges, police officials, border guards, prison officials and prosecutors only unless otherwise provided by the constitution or by law (Tymoshchuk and Shkolyk, 2007). It should be noted that public service in the judiciary in foreign countries of the world is carried out with due regard for the strict observance of the rules of international legal acts, which include: Montreal Universal Declaration of Independence of Justice, Basic Principles for the Independence of the Judiciary, Developed by the United Nations, European Charter for the Status of Judges. 
With regard to the appointment of a person to the position of a judge of a court of general jurisdiction having the status of a public servant, there is no single way of completing the corps of judges in foreign countries. Its formation may be due to appointment or election, including judicial self-government, or through mixed methods. In particular, current French law provides for the following ways of staffing judges in courts of general jurisdiction: owing to the direct appointment of a judge with a degree in law and a certain length of service in the field of legal activity; temporary appointment to the post of judge of the court of general jurisdiction of magistrates retired, who at one time held the posts of judges, prosecutors; appointment to work in a court of general jurisdiction as a judge of a graduate of the National School of Magistracy (Tymoshchuk and Shkolyk, 2007).

German law provides for the assignment of public servants to four main types of rank: "A", "B", "C", "R". These ranks " $A$ " and " $B$ " are intended for assignment to officials and military, rank " $C$ " is assigned to the teaching staff of higher education and academic institutions, rank "R" to judges and prosecutors as public prosecutors
(Ahientaieva, 2012). However, one of the most complex public service rankings has historically been in France. In particular, at the state level, for the various existing categories of posts of public servants, there is a separate subsystem of their respective titles, whose legal regulation is often different. In the context of promotion by title, French law provides for and establishes not only the minimum but also the average length of time required to stay and pursue a professional activity in public service.

Taking into account the problems we have identified in the course of our research, we believe that the implementation of the next steps in the field of public service in the system of courts of general jurisdiction will bring to a new stage the development of public administration in Ukraine.

1. Adoption of the Law of Ukraine "On Public Service". In the course of this study, we have identified the absence of a specific legal act that consolidates the functioning of the public service in Ukraine. Public administration today is declarative and purely formal in nature, since domestic law contains not only the definition of public service, but it is, as 
we noted above, imperfect. According to the experience of other countries, only in the presence of a special law adopted by the legislature is possible the development and efficient functioning of public administration. Therefore, based on the experience of foreign countries, we consider it advisable to develop a special legal act that will become the basis for laws that regulate the activities of public servants. It should enshrine: a) the concept of public service; b) types of public service; c) general principles of the legal status of public servants; d) principles of public service; e) features and functions of public administration; f) positions that perform public functions; g) conditions for admission to public service, etc.

\section{Amendments to the Law of Ukraine} "On Judiciary and Status of Judges". In order to truly recognize a general court judge as a public servant, it is necessary, first of all, to amend a special law regulating the activity of professional judges, namely the Law of Ukraine "On Judiciary and Status of Judges". The status of a judge is enshrined in Art. 52 of the Law, which stipulates that judges in Ukraine have a single status. We believe that the provisions of Part 2. Art.
52 of this Law should be amended and set forth this provision in the following wording "Judges in Ukraine have a single civil servant status regardless of the place of court in the system of courts of general jurisdiction or administrative position held by a judge". Due to the low level of public trust in judges, which is unacceptable for a democratic, social and rule of law in the present, the question of openness, transparency and publicity in the administration of justice is exacerbated. With the introduction of changes to the rule on the legal status of a judge of a court of general jurisdiction, a new concept of his activity arises, because priority in this case is placed on the exercise of powers in accordance with the public interest. Transparency, openness and publicity in this version are one of the basic principles of the functioning of the judiciary and are built directly on restoring people's trust in the judiciary, which is the purpose of the Strategy for the Reform of Judiciary, Judiciary and Related Legal Institutions for 2015-2020.

3. Introduction of categories of judges of courts of general jurisdiction. As we have defined in the previous sections, both judges and public officials are 
public servants. Therefore, in our opinion, it is appropriate to consolidate the common features that characterize public service persons. Such a feature is the division of posts of public servants into categories. Thus, according to Art. 6 of the Law of Ukraine "On Civil Service", civil service positions in state bodies are divided into categories and subcategories. The introduction of similar categories for judges of courts of general jurisdiction is well founded, since the position held should depend on the criteria which include: a) the order of appointment; b) the level of responsibility; c) level of qualification; d) scope of authority; e) the degree of complexity of the case; f) the content of the work, etc. Given the system of courts of general jurisdiction, we consider that the categories of judges should have the following form: category " $\mathrm{A}$ " - judges of the Supreme Court of Ukraine; category "B" - judges of higher specialized courts; category "C" - judges of the courts of appeal; category " $D$ " local court judges.

4. Creating a judge reporting program. With constant reformation and change in the organization of the selection of judges, public confidence in the judiciary decreases every year. This is due to the low level of legal awareness of Ukrainians, which causes the fact that more than half of the society is pessimistic about reforms and any updating of the governance system. The task today is to restore the level of public confidence in the judiciary and judges in particular. One way to solve this problem is to create a mechanism for reporting on work performed. We believe that the judge should report on the work performed once a year. The form of reporting may be public hearings, at which the judge presents a report on his / her annual activity as a judge and the results of the case. Anyone can join the hearing, ask questions at the end of the report. Thus, the judge, as a public servant, maintains direct communication with the public and satisfies the public interest. To implement this proposal, it is necessary to amend part 5 of Article 55 of the Law of Ukraine "On Judiciary and Status of Judges" and to strengthen the duty of a judge to report on the results of annual work before the society.

Therefore, we have substantiated the need for the introduction of the Concept of introducing the "judge-civil servant" model, and we are convinced that such a 
systematic approach to the functioning of the principles of public administration among judges of courts of general jurisdiction will be effective in improving not only the level of legislative regulation and public service, but also the confidence of the population of Ukraine in the existing judiciary and judges in particular.

\section{Conclusion}

Having analyzed the experience of forming a public service in foreign countries of the world, it should be noted that the approaches in its organization are closely connected with historical traditions and culture. Public service for most countries is one of the most important components of a public administration organization. The activities of judges of courts of general jurisdiction, on the one hand, are based on general principles of public service organization, on the other, they take into account the specifics and nature of the administration of justice. The experience of foreign countries points to quite different approaches to determining the place of judges of courts of general jurisdiction in the public service system and their legal status in general.
With the introduction of amendments to the Code of Administrative Procedure of Ukraine in 2016, the period of introduction of the latest technologies of functioning of justice began. However, unfortunately, the legislator does not consider improvement of the provisions on public administration a necessary and priority task of the state, since the definition of "public service" enshrined in 2005 has not yet been amended.

Therefore, the task today is to increase transparency, publicity and openness of the judiciary. Thus, since there is no specific Action Plan on this, we define the basic provisions of the Concept of Implementation of the JudgePublic Servant Model.

\section{References:}

Ahientaieva VV. (2012). Features of the Legal Status of Civil Servants in the Federal Republic of Germany. Bulletin of Zaporizhzhya National University, 9, 155-160.

Assessment of the situation in the country by the citizens, the level of trust in the executive and law enforcement agencies, evaluation of the 
Government's activity. (2020).

http://razumkov.org.ua/napriamky/sotsi

ologichni-doslidzhennia/otsinka-

gromadianamy-sytuatsii-v-kraini-riven-

doviry-do-vykonavchykh-ta-

pravookhoronnykh-organiv-vlady-

otsinka-diialnosti-uriadu-liutyi-2020r.

Bangalore Principles of Judicial

Conduct.

(2006).

https://zakon.rada.gov.ua/laws/show/99

5_j67

Basic Principles for the Independence of the Judiciary, Developed by the United Nations.

https://www.un.org/ruleoflaw/blog/docu ment/basic-principles-on-the-

independence-of-the-judiciary/

Code of Administrative Procedure of

Ukraine.

(2005).

https://zakon.rada.gov.ua/laws/show/27

47-15.

Constitution of Ukraine. (1991).

https://zakon.rada.gov.ua/laws/show/25

4\%D0\%BA/96-\%D0\%B2\%D1\%80.

Decree of the President of Ukraine No. $5 / 2015$ "On the Sustainable Development Strategy “Ukraine 2020””.
(2015).

https://zakon.rada.gov.ua/laws/show/5/2 $\underline{015}$.

European Charter for the Status of Judges. (1999). https://www.icj.org/wpcontent/uploads/2014/10/Judgescharter-in-europe.pdf.

Goncharuk NT. (2017). Modernization of the Civil Service of Ukraine at the current stage of development. Law and Public Administration, 4, 191-198.

Holobutovskyi RZ. (2019). Public service in the judiciary as an administrative and legal category. Legal Scientific Electronic Journal, 1, 127-130.

Khorosheniuk OV. (2015). Organization of Public Service in Ukraine: Theoretical and Legal Aspects. Lviv: LRIDU NADU.

Law "On Public Service" in Estonia. (2002).

https://www.jstor.org/stable/43212933? $\underline{\text { seq }}=1$.

Law of the Republic of Lithuania "On Civil Service”. (1999). www.seimas.lt. 
Law of Ukraine No. 1402-VIII "On Judiciary and Status of Judges". (2016). https://zakon.rada.gov.ua/laws/show/14 02-19.

Law of Ukraine No. 889-VIII “'On Civil

Service". (2015).

https://zakon.rada.gov.ua/laws/show/88 9-19.

Montreal Universal Declaration of Independence of Justice. (1983). https://www.jiwp.org/montrealdeceleration-1983.

Paseniuk OM. (2009). Administrative justice of Ukraine. Kyiv: Yurincom Inter.

Pchelina O, Sezonov V, MyrhorodKarpova V, Zherobkina Ye. (2019). Administrative and legal mechanism of execution of decisions of the European Court of Human Rights as the basis of case law application in the judicial system of Ukraine, 2, 34-49.

Petrenko OS. (2008). Formation of an Integrated Institute of Public Service in Ukraine. Dnipropetrovsk: Litera.
Prokopenko LL. (2009). Public service in EU countries. Public Administration: Theory and Practice, 1, 174-182.

Runova NO. (2012). Public service in Ukraine: problems of definition. Public Law, 3, 269-273.

Shatrava S, Smolyarova M, Harust Yu, Kryvosheiev K. (2019). Theoretical and legal analysis of the category" "financial security of the state". Asia Life Sciences, 2, 63-69.

Syniavyna M. (2014). Public administration and public service as a result of democratization of public administration. Law of Ukraine, 21, 6572.

Tsurkan MI. (2010). Legal Regulation of Public Service in Ukraine. Features of Litigation. Kharkiv: Pravo.

Tymoshchuk VP, Shkolyk AM. (2007). Public Service. Foreign Experience and Offers for Ukraine. Kyiv: Konus-U.

Yarmysh ON, Serohin VO. (2002). State Building and Local Self-Government in Ukraine. Kharkiv: Issue of the National University of Internal Affairs 